\title{
Penyuluhan Tentang Keterampilan Proses Sains di SMA Negeri 1 Kediri
}

\author{
Hikmawati $^{1}$ \\ ${ }^{\text {I}}$ Program Studi Pendidikan Fisika, FKIP Universitas Mataram, Mataram, Indonesia
}

*Corresponding Author: Hikmawati, FKIP Universitas Mataram, Mataram, Indonesia; Email: hikmawati@unram.ac.id

\begin{abstract}
Abstrak: Tujuan kegiatan pengabdian kepada masyarakat ini adalah memberikan pemahaman kepada peserta didik di SMA Negeri 1 Kediri tentang keterampilan proses sains. Keterampilan proses sains merupakan keseluruhan keterampilan ilmiah yang terarah yang dapat digunakan untuk menemukan suatu konsep, prinsip, atau teori untuk mengembangkan konsep yang telah ada sebelumnya, ataupun untuk melakukan penyangkalan terhadap suatu penemuan. Kegiatan ini dilaksanakan pada hari Kamis tanggal 22 Agustus 2019 di SMA Negeri 1 Kediri dengan peserta berjumlah 35 orang siswa. Kegiatan penyuluhan diawali dengan ceramah materi, dilanjutkan tanya jawab, dan terakhir latihan dengan pemberian contoh. Materi yang diberikan kepada peserta penyuluhan yaitu tentang pengertian keterampilan proses sains, klasifikasi keterampilan proses sains, dan tujuan melatihkan keterampilan proses sains. Contoh keterampilan proses sains diberikan melalui fenomena percobaan ayunan bandul. Keterampilan proses sains yang dijelaskan kepada peserta terdiri atas: 1. Merumuskan Masalah; 2. Merumuskan Hipotesis; 3. Melakukan Identifikasi Variabel Manipulasi; 4. Membuat Definisi Operasional Variabel Manipulasi; 5. Melakukan Identifikasi Variabel Respon; 6. Membuat Definisi Operasional Variabel Respon; 7. Melakukan Identifikasi Variabel Kontrol; 8. Membuat Definisi Operasional Variabel Kontrol; 9. Menafsirkan Informasi; 10. Berkomunikasi. Kegiatan penyuluhan ini telah memberikan pemahaman tentang keterampilan proses sains bagi siswa di SMA Negeri 1 Kediri.
\end{abstract}

Kata kunci: keterampilan proses sains

\section{Pendahuluan}

Fisika adalah cabang dari sains atau ilmu pengetahuan alam yang pada hakikatnya merupakan kumpulan pengetahuan, cara atau jalan berpikir, dan cara untuk penyelidikan. Dengan kata lain, fisika sebagai bagian dari sains memiliki hakikat sebagai produk ilmiah, sikap ilmiah, dan proses ilmiah. Menurut Trianto (2008) hakikat fisika adalah ilmu pengetahuan yang mempelajari gejala-gejala melalui serangkaian proses yang dikenal dengan proses ilmiah yang dibangun atas dasar sikap ilmiah dan hasilnya terwujud sebagai produk ilmiah yang tersusun atas tiga komponen terpenting berupa konsep, prinsip, dan teori yang berlaku secara universal.

Dengan mencermati hakikat fisika tersebut di atas maka pembelajaran fisika hendaknya dapat memberikan pengetahuan (kognitif), keterampilan (psikomotorik), dan kemampuan sikap ilmiah (afektif). Hal ini sesuai dengan pendapat Benyamin S. Bloom dalam Jufri (2010) yang menyatakan bahwa hasil belajar siswa dikelompokkan ke dalam tiga ranah atau domain yaitu: (1) kognitif, (2) afektif, (3) psikomotorik.

Untuk mewujudkan pembelajaran fisika yang dapat meningkatkan hasil belajar siswa pada tiga domain tersebut maka diperlukan pendekatan keterampilan proses sains sehingga siswa dapat menemukan fakta-fakta, membangun konsepkonsep, teori-teori, dan mengembangkan sikap ilmiah siswa itu sendiri. Suprihatiningrum (2013) berpendapat bahwa keterampilan proses sains adalah keterampilan yang diperoleh dari latihan kemampuan-kemampuan mental, fisik, dan sosial yang mendasar sebagai penggerak kemampuankemampuan yang lebih tinggi. Pendekatan keterampilan proses merupakan cara memandang siswa sebagai manusia seutuhnya.

Berdasarkan wawancara yang dilakukan pada siswa di SMA Negeri 1 Kediri diperoleh informasi bahwa siswa belum memahami tentang keterampilan proses sains. Hal ini mungkin menjadi salah satu penyebab masih rendahnya nilai ujian. 
Laporan Hasil Ujian Nasional Tahun Pelajaran 2017/2018 di Kabupaten Lombok Barat, Program Studi IPA, menunjukkan bahwa nilai ujian pada mata pelajaran fisika yang diperoleh siswa SMA termasuk dalam kategori kurang. Menurut Puspendik (2018), nilai rata-rata siswa sebesar 36,06 dengan nilai terendah siswa sebesar 20,0 dan nilai tertinggi sebesar 77,5. Jumlah peserta yang mengikuti ujian sejumlah 1281 siswa yang berasal dari 17 sekolah SMA negeri dan swasta yang tersebar di Kabupaten Lombok Barat. Statistik nilai ujian tersebut dapat dilihat pada Tabel 1.

\section{Tabel 1 Statistik Nilai Tahun Pelajaran} 2017/2018

\begin{tabular}{|c|c|c|c|}
\hline \multirow{2}{*}{ Statistik } & \multicolumn{3}{|c|}{ Nilai Per Mata Pelajaran } \\
\cline { 2 - 4 } & Fisika & Kimia & Biologi \\
\hline Kategori & Kurang & Kurang & Kurang \\
\hline Rata-Rata & 36,06 & 46,86 & 38,43 \\
\hline Terendah & 20,0 & 20,0 & 15,0 \\
\hline Tertinggi & 77,5 & 77,5 & 87,5 \\
\hline Standar Deviasi & 9,49 & 11,21 & 11,06 \\
\hline
\end{tabular}

Berdasarkan hal tersebut di atas maka diperlukan upaya untuk meningkatkan hasil belajar siswa, salah satunya adalah dengan melaksanakan kegitan pengabdian kepada masyarakat yaitu dengan memberikan penyuluhan tentang keterampilan proses sains pada siswa SMA di Kabupaten Lombok Barat. Tujuan kegiatan pengabdian kepada masyarakat ini adalah memberikan pemahaman kepada peserta didik di SMA Negeri 1 Kediri tentang keterampilan proses sains.

\section{Metode}

Kegiatan pengabdian kepada masyarakat ini dilaksanakan pada hari Kamis tanggal 22 Agustus 2019 di SMA Negeri 1 Kediri dengan peserta berjumlah 35 orang siswa. Kegiatan penyuluhan diawali dengan ceramah materi yang berhubungan dengan keterampilan proses sains, dilanjutkan tanya jawab, dan terakhir latihan dengan pemberian contoh. Materi yang diberikan kepada peserta penyuluhan yaitu tentang pengertian keterampilan proses sains, klasifikasi keterampilan proses sains, dan tujuan melatihkan keterampilan proses sains. Contoh keterampilan proses sains diberikan melalui fenomena percobaan ayunan bandul.
Keterampilan proses sains yang dijelaskan kepada peserta terdiri atas 10 komponen yaitu: 1 . Merumuskan Masalah; 2. Merumuskan Hipotesis; 3. Melakukan Identifikasi Variabel Manipulasi; 4. Membuat Definisi Operasional Variabel Manipulasi; 5. Melakukan Identifikasi Variabel Respon; 6. Membuat Definisi Operasional Variabel Respon; 7. Melakukan Identifikasi Variabel Kontrol; 8. Membuat Definisi Operasional Variabel Kontrol; 9. Menafsirkan Informasi; 10. Berkomunikasi.

\section{Hasil dan Pembahasan}

Materi penyuluhan yang disampaikan pada kegiatan pegabdian kepada masyarakat ini adalah sebagai berikut.

1. Pengertian keterampilan proses sains

Semiawan (1986) menjelaskan bahwa pendekatan keterampilan proses merupakan alat untuk memecahkan masalah yang dapat memberikan kemampuan atau keterampilan memproses perolehan, sehingga siswa mampu menemukan dan mengembangkan sendiri fakta, konsep, sikap, dan nilai. Keterampilan proses sains adalah keterampilan intelektual yang membekali siswa dengan suatu kemampuan berpikir logis, dan sistematis dalam menghadapi suatu permasalahan. Keterampilan memproseskan perolehan tersebut dapat membuat siswa mampu menemukan dan mengembangkan sendiri fakta dan konsep serta menumbuhkan dan mengembagkan sikap serta nilai yang dituntut.

2. Klasifikasi keterampilan proses sains

Menurut Funk (dalam Indrawati, 2000), keterampilan proses sains diklasifikasikan menjadi 2 yaitu: keterampilan proses sains tingkat dasar (basic science process skill) dan keterampilan proses sains terpadu (integrated science process skill). Keterampilan proses sains tingkat dasar terdiri atas: observasi, klasifikasi, komunikasi, pengukuran, prediksi, dan inferensi. Keterampilan proses sains terpadu terdiri atas: menentukan variabel, menyusun tabel data, menyusun grafik, memberi hubungan variabel, memproses data, menganalisis penyelidikan, menyusun hipotesis, menentukan variabel secara operasional, merencanakan penyelidikan, dan melakukan eksperimen.

3. Tujuan melatihkan keterampilan proses sains. 
Trianto (2008) mengatakan bahwa melatihkan keterampilan proses merupakan salah satu upaya untuk memperoleh keberhasilan belajar siswa yang optimal. Materi pelajaran akan lebih mudah dipahami dan akan diingat relatif lebih lama karena siswa belajar melalui pengalaman langsung atau eksperimen.

Contoh keterampilan proses sains diberikan melalui fenomena percobaan ayunan bandul yaitu sebagai berikut.

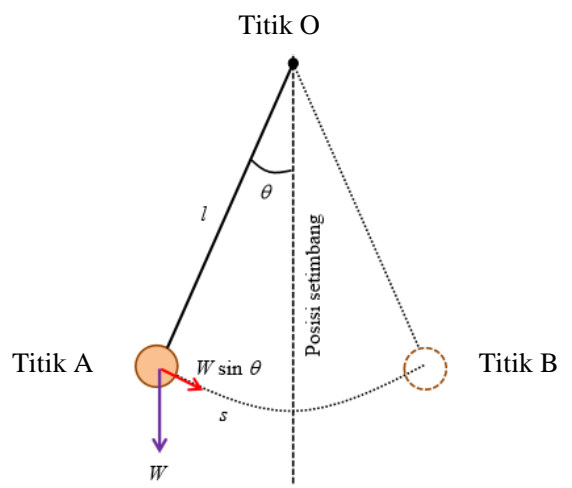

Gambar 1. Skema ayunan bandul (Abdullah, 2016)

Rumusan masalah: Bagaimana pengaruh panjang tali $(l)$ terhadap periode bandul $(T)$ ? Rumusan hipotesis: Jika panjang tali $(l)$ semakin besar maka periode bandul ( $T$ ) semakin besar. Identifikasi variabel manipulasi: panjang tali $(l)$. Identifikasi variabel respon: periode bandul $(T)$. Identifikasi variabel kontrol: simpangan $(\theta)$. Definisi operasional variabel manipulasi: panjang tali merupakan panjang tali bandul yang diukur dari titik gantungan ke ujung bandul (dari titik $\mathrm{O}$ ke titik A), diukur dengan menggunakan meteran. Definisi operasional variabel respon: periode bandul $(T)$ merupakan waktu yang dibutuhkan bandul untuk satu kali gerakan bolak-balik dari titik A ke titik B dan kembali lagi ke titik $\mathrm{A}$, diukur dengan menggunakan stopwatch. Definisi operasional variabel kontrol: simpangan $(\theta)$ merupakan besarnya sudut simpangan ayunan bandul dari posisi setimbang, diukur dengan menggunakan busur derajat, yang dibuat tetap sebesar $15^{\circ}$. Berkomunikasi: membuat grafik hubungan antara panjang tali $(l)$ terhadap kuadrat periode bandul $\left(T^{2}\right)$. Menafsirkan informasi: menyimpulkan berdasarkan tabel hasil pengamatan dan grafik.

Beberapa dokumentasi kegiatan pengabdian kepada masyarakat ini adalah sebagai berikut.

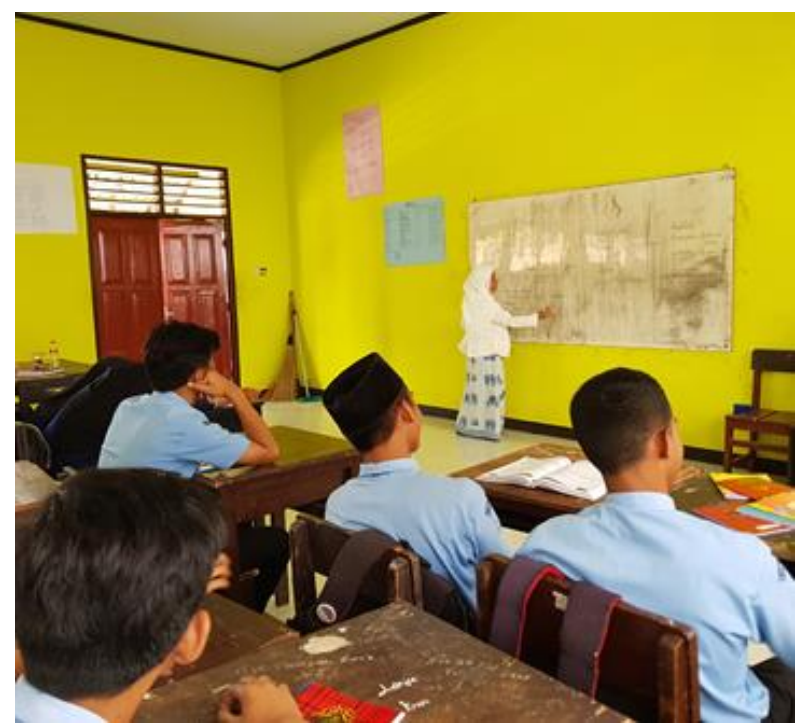

Gambar 2. Pemateri sedang menjelaskan keterampilan proses sains

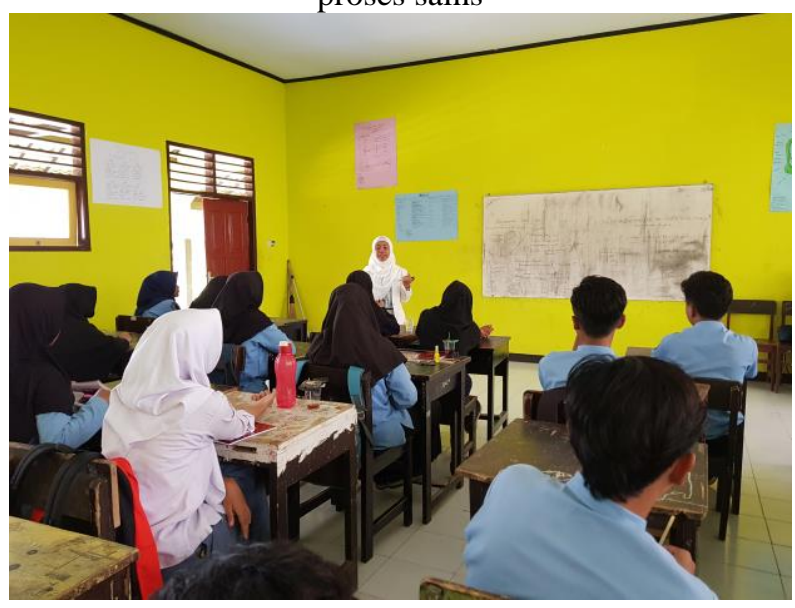

Gambar 3. Peserta kegiatan memperhatikan penjelasan materi tentang keterampilan proses sains

\section{Kesimpulan}

Kegiatan pengabdian kepada masyarakat berupa penyuluhan ini telah memberikan pemahaman tentang keterampilan proses sains bagi siswa di SMA Negeri 1 Kediri.

\section{Saran}

Penyuluhan tentang keterampilan proses sains bagi siswa di SMA Negeri 1 Kediri ini berjalan dengan lancar. Semoga pengabdian ini bisa dilanjutkan dan ditingkatkan pelakasaannya di masa yang akan datang. 


\section{Ucapan Terima Kasih}

Penulis mengucapkan terima kasih kepada Universitas Mataram melalui Lembaga Penelitian dan Pengabdian kepada Masyarakat (LPPM) yang telah membiayai kegiatan pengabdian ini. Selain itu, ucapan terima kasih juga disampaikan kepada peserta didik SMA Negeri 1 Kediri yang menjadi peserta dalam kegiatan ini.

\section{Daftar Pustaka}

Abdullah, M. 2016. Fisika Dasar I. Bandung: Institut Teknologi Bandung.

Indrawati. 2000. Keterampilan Proses Sains/IPA. Bandung: PPPGIPA.

Jufri, A.W. 2010. Belajar dan Pembelajaran Sains. Lombok Barat: Arga Puji Press.

Puspendik. 2018. https://puspendik.kemdikbud.go.id/hasilu n/ diakses tanggal 5 Februari 2019.

Semiawan, C. 1986. Pendekatan Keterampilan Proses: Bagaimaana Mengaktifkan Siswa. Jakarta: Gramedia.

Suprihatiningrum, J. 2013. Strategi Pembelajaran: Teori \& Apikasi. Jogjakarta: Ar-Ruzz Media.

Trianto. 2008. Mendesain Pembelajaran Kontekstual (Contextual Teaching and Learning) di Kelas. Jakarta: Cerdas Pustaka. 